\title{
Academic Orientation in Preschool Education
}

\author{
Mohamad Samsudin ${ }^{1, a^{*}}$, Husni Rahim ${ }^{1, b}$, and Didin Saepudin ${ }^{1, c}$ \\ 1Islamic Studies, Postgraduate Program, Universitas Islam Negeri Jakarta, Indonesia \\ a mohamadsamsudin@stai-nuruliman.ac.id ; b husni.rahim@uinjkt.ac.id; c didin.saepudin@uinjkt.ac.id \\ *Corresponding Author: mohamadsamsudin@stai-nuruliman.ac.id |Phone Number: 082114114141
}

\begin{abstract}
Currently, preschool education has evolved, even it has been revolutionized. This fact is shown by the large content of academic teaching materials such as reading, writing, and arithmetic which is still controversial must be taught in preschool education, which seems to be a compulsory subject for preschool children. Although government regulations have regulated properly and ideally how preschool education should be implemented, ironically due to competition between preschool institutions and the demands of parents, many preschool institutions fulfill their curricula with academic content. This study aims to obtain an overview of the academic-oriented preschool learning process in planning, implementation, and evaluation.
\end{abstract}

Keywords: Academic Orientation; Preschool Education; Learning Process; Kindergarten

\section{Introduction}

Generally, the purpose of preschool education is to provide care and education. Caring is defined as meeting the needs of children by providing a safe environment, nutrition, and adequate rest. While education is intended to guide children to grow and develop as a whole which includes social, emotional, physical, and intellectual development (Burger, 2013). To meet every child's growth and development needs, the preschool education process requires a holistic learning approach. Good preschool education is education that is able to understand that the socioemotional, physical, linguistic, spiritual, and moral aspects of development are as important as cognitive development (Ogunnaike, 2015). Thus, Preschool education theoretically provides a framework for understanding the nature, abilities, and how to create a learning environment that enhances children's overall development.

In the Indonesian context, the goals of preschool education have been determined based on the philosophy of life, sociocultural and the ideals of the Indonesian nation, namely to build a foundation for the development of children's potential to become human beings who believe and fear God, have a noble character, noble, healthy, knowledgeable, competent, critical, creative, innovative, independent, confident, being democratic and responsible citizens, developing the potential of spiritual, intellectual, emotional, kinesthetic, and social intelligence of students in their golden age of growth in an educational and fun play environment (PP N0. 17, 2010).

Today, preschool education has evolved, even according to Hachey it has been revolutionized. This occurs due to a change in paradigm and perspective on children's math abilities after recent findings of cognitive psychology in the 1960s (Hachey, 2013). This change in paradigm made preschool education change from previous learning patterns. If the old paradigm considers the function of preschool education to direct children to the ability to socialize with the surrounding environment, now the orientation has changed to academic ability. The change in paradigm, according to Hatch, occurred because of a fundamental change in three things, namely: (1) the childhood experiences of children today are different from those of a decade ago; (2) knowledge of how children learn and develop has been expanded; and (3) the standards-based reform movement has changed expectations for improving children's academics (Hatch, 2005).

On the other hand, scientific research has also concluded that the academic and social experiences of preschoolers are related to school readiness and learning outcomes at higher levels (primary and secondary schools) which are defined as language and math skills. This research evidence is a strong reason to encourage academic learning approaches in preschool education. The preschool curriculum must provide some early childhood academic skills for their success in their next education so that the implementation of 
the curriculum reduces the type of learning method for preschool children, namely the play method. Not a few preschool students have been required to develop various basic academic skills such as mastering reading, writing, and arithmetic. School preparation for preschoolers has been interpreted by many as the ability to achieve academic competence (Brown, 2013).

Jalongo said the preschool curriculum must be academically oriented, such as being formally involved in arithmetic, reading, and writing to face the information age. According to him, children in modern times like today tend to prefer to seek information through electronic media which is full of reading and writing. Therefore, prospective first-grade elementary school students must be equipped with academic skills such as arithmetic so that they can easily learn mathematics and are better prepared to enter the next level of education (Jalongo, 2015). This perspective is accepted by some to improve their child's future by gaining knowledge and having math skills from childhood. Some people believe that this has the advantage of furthering the development of their children's math skills at later levels of education. It is for this reason that Soydan views it is very important to support children to formally introduce mathematics education at preschool age so that they will enjoy mathematics while learning and are not afraid of math exercises of the future (Soydan, 2015). Thus, the academic approach has played a major role in the preschool curriculum. Emphasis on children's academic abilities is done by the preschool program. This is due to the increasingly tight competition between preschool education institutions. So, many preschool educational institutions are pursuing target student acquisition by selling out programs without considering the aspects of child development.

Starting from the above problems, the investigation of academic orientation in preschool education is important and necessary. This study is to describe how the preschool learning process, including planning, implementation, and evaluation, is full of academic nuances. In addition, this research is also expected to contribute to the next preschool education stakeholders. The determination of the problem in this research is increasingly important because: First, the density of learning materials (learning to read, write and count) in early childhood is still a serious topic of discussion in education circles. Second, many preschool educational institutions ignore the development of their students by providing learning materials and various activities. Third, an understanding of education that is in line with child development for education stakeholders is very important because with it the educational process will suit the needs of the child without having to sacrifice the child himself.. Fourth, the academic-oriented learning process in educational institutions has actually occurred without being realized by the education implementer and the child's parents. This study aims to obtain an overview of the academic orientation preschool learning process in planning, implementation, and evaluation

\section{Philosophical Orientation of Preschool Education}

The term preschool education refers to educational services whose students are preschool children, namely children who are still in preparation for formal schooling. In Indonesia, preschool children are between 0 and 6 years old. Programs that are followed are Child Care Centers (Tempat Penitipan Anak) for ages three months to five months and Play Groups (Kelompok Bermain) for ages three years. As for children aged 4-6 years, they usually attend Kindergarten (Taman Kanak-kanak) or Islamic Kindergarten (Raudhatul Athfal) programs (UU-Sisdiknas No. 20, 2003).

There are basic assumptions that can be used as a conceptual and philosophical basis for seeing the essence of preschool education, namely: children need special care, children are the future of society, children are human learners, and children's potential must be optimized (Sharp, 2016). From these basic assumptions, ideas emerged about how children learn and how best to teach children, which then formulated principles such as (1) Learning occurs through play (play-based learning); (2) Children have a natural tendency to explore; (3) Children should be encouraged to find knowledge; (4) The teacher must develop what the child already knows; (5) The teacher is a guide on the child's side; and (6) Learning must be through experience and be concrete in nature (Farquhar, 2014).

Philosophically, the emergence of various concepts of child education basically begins with an understanding of the child himself as a social and cultural construction, which is then reflected in the educational process as set out in a series of curricula and its implementation. Child development is a social and cultural process because children do not grow alone. They learn to think, feel, communicate, and act in social relationships whose cultural contexts and practices are mediated by beliefs about how children should be treated, what it means to be a child, and when childhood begins and ends (Lee, 2013).

Globally, early childhood education also occupies an important platform for the nation's economic and social policies. It is assumed that the better the role of parents and the state in the welfare of children, both in terms of care and education, the children will be able to meet the future of the nation in the contemporary world. From this paradigm emerges the belief that early childhood education accompanied by good care can 
be framed into early childhood education programs which are often considered by most countries in the world as a magic bullet social reform. In addition, the portrait of child welfare is an important indicator in seeing the condition of a nation and a country around the world (UNICEF, 2007).

\section{Dynamics of Preschool Education at Sociological Empirical Level}

Speaking of preschool education, especially at the kindergarten level, it is inseparable from the father of kindergarten, Froebel (1782-1852) who founded the first garden of children or kindergarten in 1837 AD in Blakenburg, Germany. This kind of kindergarten model designed by Froebel became an example of kindergarten in England, France, the Netherlands, and finally the United States, even in parts of the world. Froebel develops her preschool education with designs to create harmony between God, children, and the natural surroundings. Froebel believes that the purpose of education is to understand the relationship between the Creator (God) and beings (both living and non-living) that are harmoniously intertwined on earth (Nutbrown and Clough, 2014).

According to Froebel, there are three forms of knowledge that form the basis of children's learning, namely: first, knowledge of forms of life such as gardening, animal care, and household tasks; second, knowledge of forms of mathematics such as geometric shapes and their relationship to each other; and third, knowledge of forms of beauty (knowledge of forms of beauty) such as the design with colors and shapes, harmony, and movement. To provide these three pieces of knowledge, Froebel designed a special learning media called "gifts." Apart from the above, Froebel also uses a method of handwork activities called occupations such as printing, cutting and folding paper, arranging beads, and embroidery (Provenzo, 2009).

However, in the early 1900s, several factors (including anti-German sentiment and a desire to create an industrial-oriented approach to education) triggered the rapid decline of Froebel's kindergarten method. On the other hand, the reading and mathematics curriculum model is designed for preschool children specifically for economically disadvantaged children. Froebel's educational philosophy is labeled as education that is too fun, even too indulgent for children (romantic education). As a result, many educational methods and media that actually contained Froebel's brilliant ideas were lost due to the abuse and misunderstanding of child education practitioners at that time (Morrison, 2004). This phenomenon is the reason Jeynes in the conclusion of his research which states that the Froebel kindergarten model has now changed its originality because it presses students to master various academic abilities and imposes higher standard tests. Many kindergarten programs are centered on teaching materials rather than on the childcentered Froebel envisioned (Corter and Wolanski, 2006). Thus, this description shows that there has been a change in learning models and strategies in preschool education.

\section{Controversial Issues Related to Academic Orientation in Preschool Education}

Basically, preschool education currently appears to have two different orientations in the implementation of the learning process, namely academic-oriented and socioemotional-oriented (Russell, 2011). Academicoriented preschool education refers to a view that focuses on the resulting output must master various academic abilities such as literacy (reading and writing) and mathematics (arithmetic) (Richman and Rescorla, 2015). Meanwhile, the socioemotional orientation refers to how children are able to adapt socially both to their peers and their environment, to be able to control emotions, and to change their personality for the better (Kluczniok, 2015).

Armstrong characterizes academic-oriented preschool educational institutions by (1) densities of academic-nuanced material such as the ability to read, write and count; (2) reduced playing activities as a vehicle for children's learning; (3) evaluation of learning outcomes using standardized academic scores; (4) oriented to results, not a learning process; (5) a strict, uniform, and applicable curriculum for all students (Armstrong, 2006). Both preschool education orientations are reflected in how to plan, implement, and evaluate in learning process.

Child education experts have raised concerns about the increasing formalization of preschool education. In the United States, academics have long debated and questioned the principles of preschool education, where the curriculum since the 1980s has led to an emphasis on child development with child achievement tests (Soto \& De Moed, 2011). In Australia, many studies have criticized policy reforms in the early childhood education sector driven by a socio-economic investment agenda that raises different demands on education stakeholders and has an impact on preschool education services (Irvine and Farrell, 2013; Moss, 2013) . Likewise in England, on September 12st 2013, there was a massive campaign carried out by more than one hundred professionals from various elements of society, such as academics, teachers, practitioners, and education advisors in response to the emergence of a new policy from the government that changed the perception of preschool education to education is oriented towards school preparation. The campaign, entitled Too Much Too Soon Campaign, expresses strong concern over the increasing use of 
academic tests (reading and writing counts) which is enforced at the age of four years (The Telegraph, 2013).

The same thing happened in Hong Kong and Southeast Asia. Academics have raised concerns about the tremendous emphasis on target-oriented preschool education curricula and academic-oriented curricula. Research conducted by Fung and Cheng, for example, reports that the emergence of tension in the role of preschool education originates from the expectations of parents who regard preschool education as the basis for starting the primary school system. Starting from this concern, parents put pressure on preschool educational institutions so that their children are better prepared to enter primary school (Fung and Cheng, 2012).

Many studies have shown that the academic approach to the preschool curriculum is less satisfying than expectations. Take the case in Germany where most of the kindergartens there are play-based turned into centers of achievement of academic ability due to educational reforms in the 1970s. However, research comparing 50 play-based kindergarten classes with 50 academically-based kindergarten classes found that at the age of 10 years later, children resulting from play-based kindergarten outperformed others in a wide range of skills. They were more advanced in reading and math and were better socially and emotionally at school. They excel in creativity and intelligence, oral expression, and are able to work (Biedinger, 2010). Based on this research, Kindergarten in Germany is now returning to play-based kindergarten (Miller and Almon, 2009). Likewise, in Japan and China, which managed to catch up in the fields of science, mathematics, and technology from America, there was no academic learning before the second grade of elementary school. All kindergarten children carry out their learning process by playing full of fun without emphasis (Tobin, et.al, 2011). Likewise, Finland is a country that scores the highest on the PISA exam and is respected internationally in the fields of science and mathematics. Children there enjoy kindergarten education by playing and enter primary school only at the age of seven (Soh, 2014) .

\section{Materials And Methods}

This research was conducted at Taman Kanak-kanak/TK (Kindergarten) Aya Sophia Islamic School in Tangerang, Banten, Indonesia. The research method applied descriptive qualitative. The approach used in this research is the psychological and pedagogical development approach. Through the psychological development approach, children will be seen as unique and special individuals. Meanwhile, through a pedagogical approach, researchers will see how the learning concept of preschool children is actualized in the school curriculum, lesson planning, learning implementation, learning material content, and learning evaluation in preschool educational institutions that are being studied.

Furthermore, to be able to conclude whether the preschool educational institution under study belongs to the academic-oriented preschool education category or not, the researchers used the academic-oriented characterization of preschool educational institutions as said by Armstrong with the following characteristics: (1) density of academic nuances such as reading ability, writing, and arithmetic; (2) reduced playing activities as a vehicle for children's learning; (3) evaluation of learning outcomes using standardized academic scores; (4) oriented to results, not a learning process; (5) a strict, uniform, and applicable curriculum for all students.

The data in this study consisted of two kinds, namely primary data and secondary data. Primary data includes documentation, interviews, and observations related to the learning process. Document data were obtained from documents of TK Aya Sophia Islamic School in the form of institutional profiles and curriculum. The profile of the institution includes history, vision-mission and objectives, strategies, goals, potentials, and learning programs. Meanwhile, the curriculum is divided into two documents, namely Document I and Document II. A document I describes the vision, mission, and objectives of the preschool program, management structure, learning content, learning load management, educational calendar, and the level of achievement of children's development. Meanwhile, Document II contains references to learning themes, annual, weekly (RPPM), and daily (RPPH) learning plans, and assessments of child development. Document data is also obtained from textbooks, report books, reading achievement cards, worksheets, and other learning resources in the form of references needed in children's learning at preschool educational institutions. Interviews were conducted with headmaster of preschool programs, six teachers, ten parents of students, and two students. The observation technique in this study was carried out by recording the information witnessed during the study using observation sheets and field notes. The secondary data includes education laws and their derivatives as well as library data obtained from several research journals, books, and other papers relevant to the discussion. The research was conducted for two years (2018-2019), starting from collecting data, analyzing data, and drawing conclusions. 


\section{Results And Discussions}

\subsection{Planning of Learning in Preschool Education}

From the planning aspect, this study found that planning of learning in preschool education does not show any application that shows a playful learning model. This is evidenced by the absence of planning for the use of the Beyond Center and Circle Time Model (Model Pembelajaran Sentra) which requires mapping of classes into small classes called centers. There is not a single class in this preschool educational institutions that describe this Beyond Center and Circle Time Model, even though the corners of the class are neatly arranged with various educational games (Alat Permainan Edukatif). All classes are designed for Classical Learning Model such as learning elementary school children. The obstacle faced by the two preschool educational institutions related to the Beyond Center and Circle Time Model is the limited classrooms that do not allow it to be divided into several centers. The lack of teachers is also an obstacle in implementing this Beyond Center and Circle Time Model because when children play in certain centers the teacher must provide support and guidance in developing the competencies to be achieved.

The lesson plans, whether yearly, monthly, weekly, or daily, all do not show any development of themes into more detailed sub-themes. Whereas sub-themes and sub-themes are "bridges" that lead children to achieve all expected dimensions of development. Because, the learning process in preschool education is not in the form of subjects like primary and secondary schools, but in the form of themes and sub-themes. If the theme is not developed into a sub-theme, the teacher will lose direction in carrying out the learning process in the classroom, especially identifying which dimensions of development the child has and wants to achieve.

The themes that are designed in the lesson planning are not continuous and cannot be translated into the theme peak activity which serves as the conclusion of all the concepts and activities carried out throughout the theme. This is because the theme peak is not carried out after the theme has been discussed, but the theme peak is only carried out in accordance with the annual moments. Thus, the theme peak loses its function as an effort to strengthen the basic competencies of child development. Because the theme peak is only interpreted as a recreational program. So, if the theme peak activities carried out in the annual event are the same as narrowing the meaning of the theme and even being far from the theme framework that has been determined in the lesson planning.

\subsection{Implementation of Learning in Preschool Education}

From the observations of learning activities at preschool educational institutions that have been studiedfrom the opening stage to the closing stage, it can be seen that it does not carry out a thematic approach. Although the presentation of the theme material is carried out in the implementation of learning, it can be said that the presentation is only modest. Presentation of theme material in learning activities is only done briefly as an effort for the teacher to manage the class. The teacher only tells about things that he thinks are relevant to the situation of the children at that time and which are considered to encourage the children before learning begins. While the method used is the method of story and question and answer. Some children asked questions related to the themes discussed, but some simply listened. Occasionally the teacher uses the blackboard to draw pictures about a theme, such as cars or nature.

The implementation of thematic learning activities using story and question-answer methods can actually be said to be less precise. Thematic learning in preschool education should integrate several subject of the lesson with children's early experiences as the basis for children's activities. That is, thematic learning is not presented by the way children listen to stories only, but the orientation of this learning is children's activities. Through the themes discussed, it is hoped that children will be able to understand how different activities and ideas are related.

The difficulty of the teacher in developing themes when learning activities take place is due to the absence of careful planning in the weekly learning implementation plan (RPPM) and the daily learning implementation plan (RPPH). None of these themes are developed into a sub-theme or even a sub-theme. Even in its presentation, the teacher only tells about the theme chosen according to the teacher's wishes. This is because teachers do not bring RPPH when teaching in class so that themes that should be discussed regularly and continuously are ignored in their implementation.

When several observations were made of the process of learning activities in this study, none of the teachers carried RPPH in the classroom as teaching guidelines. Each teacher only brings textbooks that the child will discuss and work on every day. This is because teaching has been considered a daily routine. On the one hand, they consider that thematic learning is not a priority. One of the teachers explained that the discussion of themes in learning did not have a significant impact on the development of children's knowledge, because the children already knew and even more understood the theme. This suggests that the 
thematic approach which is substantially the only approach in preschool education is missing from its implementation aspect.

In the learning activities in preschool education that were researched, it was clear that the learning model used was not a play learning model, but a classical learning model. This is evidenced by the learning pattern carried out by all children in one class at the same time without any play centers. This classical learning model is actually a conventional learning model that caused by limited learning facilities so that it emphasizes learning activities in the classroom. The characteristics of the Classical Learning Model describe its orientation which emphasizes what children learn, not how children learn. In this classical learning model, children are required to always focus on the lesson, the class must be quiet, and all children sit in their respective places following the teacher's description. Classical learning tends to put children in a passive position as recipients of learning material. Even though philosophically, preschool learning is the opposite, which emphasizes how children develop through the learning process, not being fixated on what is learned.

The learning activities is also dominated by studying textbooks that are full of academic material. Seeing the many references to textbooks with so many pages indicates that it is difficult to say if the textbooks do not dominate the entire learning process. Not to mention the content of the material whose level of difficulty exceeds the level of reasoning of preschool children. If all textbook references must be completed within one semester or one year, then it becomes clear that this shifts the essential activities of preschool education, such as the thematic approach, playing by learning, and children's play activities.

\subsection{Evaluation of Learning in Preschool Education}

Learning evaluation in preschool education still does not cover all aspects that should be evaluated. The supervision carried out by the supervisor, for example, has not touched the substantial aspects of coaching teacher teaching activities, such as teaching planning, teaching methods, learning evaluation, and so on. In carrying out supervisory duties, supervisors are limited to checking teacher administration without visiting classes during the learning process. In fact, to see a holistic learning process cannot be seen only from the administrative aspect, but how a teacher implements the administration that has been made.

On the other hand, the school committee's function is not yet functioning optimally due to the limited space to participate in supervising and supporting the improvement of the quality of preschool education. The limited space for the school committee to move is caused by familiar factors that often occur in educational foundations. In addition, the full authority possessed by the owner foundation sometimes prevents school committees from feeling free to convey constructive criticism. The authoritarian nature of sometimes arises because they feel that the capital for the establishment and development of the institution is from their personal capital. With this reality, the role and function of the school committee become just in name.

Meanwhile, the evaluation of children's learning outcomes, especially from the implementation aspect, has not touched the holistic-integrative aspects of child development. It is proven by the technique of observing child development which is not carried out every day or every week as it should be but at the end of the semester. Assessing the development of children's attitudes, apart from knowledge, is only limited to what the teacher remembers. Everything is focused on assessing how children are able to complete the textbooks they are studying. This is influenced by teachers' perceptions of children's learning outcomes which refer to textbooks with academic nuances.

\section{Conclusion}

The study concluded that the academic-oriented learning process in preschool education is carried out with a classical learning model which refers to the use of textbooks with flexible and varied learning methods and takes place in a pleasant and not boring atmosphere.

This academic orientation can be seen from the lesson planning that is designed without the development of a theme into a more detailed sub-theme so that it cannot be embodied in the peak activity of the theme which serves as the conclusion of all concepts and activities carried out throughout the theme. In addition, the classroom arrangement also does not indicate a learning model with a playful nuance. The learning implementation uses the Classical Learning Model with learning materials that are dominated by studying textbooks through varied and flexible learning methods with learning patterns that are not too strict and tense. The learning atmosphere is made as comfortable as possible, so that the learning process takes place in a pleasant but orderly atmosphere. Meanwhile, the evaluation of children's learning outcomes tends to prioritize the achievement of academic abilities which refers to the textbooks. 


\section{References}

Armstrong, Thomas. (2006). The Best Schools : How Human Development Research Should Inform Educational. Virginia, USA: ASCD Press.

Biedinger, Nicole. (2010) Early Ethnic Inequality: The Influence of Social Background and Parental Involvement on Preschool Children's Cognitive Ability in Germany. Child Ind Res, (3), 11-28. DOI $10.1007 /$ s12187-009-9054-6.

Burger, Kaspar. (2013). Early Childhood Care and Education and Equality of Opportunity: Theoretical and Empirical Perspectives on Social Challenges. Chicago: Springer Science \& Business Media.

Brown, Christopher P. (2013). Reforming Preschool to Ready Children for Academic Achievement: A Case Study of the Impact of Pre-K Reform on the Issue of School Readiness. Early Education and Development, 24, 554-573. DOI: 10.1080/10409289.2012.694352.

Corter, Carl and Aimee Wolanski. (2006). review of Standardized Tests and Froebel's Original Kindergarten Model. by William H. Jeynes. Teachers College Record, 108(10), 483-487.

Farquhar, S. \& E.J. White. (2014). Philosophy and Pedagogy of Early Childhood. Educational Philosophy and Theory, Vol. 46, No. 8, 821-832, http://dx.doi.org/10.1080/00131857.2013.783964

Fung, Chanel Kit Ho and Doris Pui Wah Cheng. (2012). Consensus or Dissensus? Stakeholders' Views on the Role of Play in Learning. Early Years, 32(1), 17-33.

Republic of Indonesia Government Regulation No. 17 of 2010 concerning Management and Implementation of Education

Hachey, Alyse C. (2013). The Early Childhood Mathematics Education Revolution. Early Education and Development, 24, 419-430. DOI: 10.1080/10409289.2012.756223.

Hatch, J. Amos. (2005). Teaching in the New Kindergarten Clifton Park, NY: Thomson Delmar Learning.

Irvine, Susan and Ann Farrell. (2013). Are We There Yet? Early Years Reform in Queensland: Stakeholder Perspectives on the Introduction of Funded Preschool Programmes in Long Day Care Services. International Journal of Early Childhood, 45 (2), 221-236.

Jalongo, Mary Renck. (2015). Information Literacy in Early Childhood: What, Why, How, and Where to Next?. Kelly L. Heider and Mary Renck Jalongo (eds), Young Children and Families in the Information Age: Applications of Technology in Early Childhood. New York: Springer Science+Business Media.

Kluczniok, Katharina. et.al.. (2016). Influences of an Academically Oriented Preschool Curriculum on the Development of Children-Are There Negative Consequences for the Children's Socioemotional Competencies?. Early Child Development and Care, 186, (1), 117-139, DOI: 10.1080/03004430.2014.924512.

Lee, Nick. (2013). Childhood and Biopolitics: Climate Change, Life Processes and Human Futures. New York: Palgrave Macmillan.

Miller, Edward and Joan Almon. (2009). Crisis in the Kindergarten: Why Children Need to Play in School?. College Park, MD: Alliance for Childhood Press.

Morrison, George S. (2004). Early Childhood Education Today, 9th edition. New Jersey: Pearson Education, Inc,

Moss, Peter. (2013): Beyond the Investment Narrative. Contemporary Issues in Early Childhood, 14 (4), 370372.

Nutbrown, Cathy and Peterr Clough. (2014). Early Childhood Education: History, Philosophy and Experience, 2nd Ed.. London: SAGE Publications Ltd.

Ogunnaike, Yomi A. (2015). Early Childhood Education and Human Factor: Connecting Theories and Perspectives. Review of Human Factor Studies 21 (1), 9-26.

Provenzo, Eugene F. Jr.. (2009). Friedrich Froebel's Gifts Connecting the Spiritual and Aesthetic to the Real World of Play and Learning. American Journal of Play, 2 (1), 85-99.

Richman, Elizabeth R. and Leslie Rescorla. (2015). Academic Orientation and Warmth in Mothers and Fathers of Preschoolers: Effects on Academic Skills and Self-Perceptions of Competence. Early Education and Development, 6 (3), 197-213, DOI: 10.1207/s15566935eed0603-1.

Republic of Indonesia Law No. 20 of 2003 concerning the National Education System

Russell, Jennifer Lin. (Apr 2011). From Child's Garden to Academic Press: The Role of Shifting Institutional Logics in Redefining Kindergarten Education. American Educational Research Journal, Vol. 48 No.2, 236-267.

Sharp, L. Kathryn. (2016). Examining the Precepts of Early Childhood Education: The Basics or the Essence?. International Journal of the Whole Child, 1-9.

Soh, Kaycheng. (2014). Finland and Singapore in PISA 2009: Similarities and Differences in Achievements and School Management. Compare, 44(3), 455-471. 
Soto, Lourdes Diaz \& Simone Tuinhof De Moed. (2011). Toward 'Our Ways of Knowing' in the Age of Standardization. Contemporary Issues In Early Childhood, Vol. 12 No. 4, 327-331.

Soydan, Sema. (2015). Analyzing Efficiency of Two Different Methods involving Acquisition of Operational Skills by Preschool Children. Eurasia Journal of Mathematics, Science \& Technology Education, 11, (1), 129-138.

Tobin, Joseph. et. al. (2011). Preschool in Three Cultures Revisited: China, Japan, and The United States. Children \& Society, Vol. 25, 172-174.

Too Much, Too Soon Campaign. (12 September 2013). The Telegraph UK. http:/ / www.toomuchtoosoon.org/open-letter.html. (accessed June 12, 2016)

UNICEF. (2007). Child Poverty in Perspective: An Overview of Child Wellbeing in Rich Countries (Florence: UNICEF Innocenti Research Centre, Report Card 07. https://www.unicefirc.org/publications/pdf/rc7_eng.pdf. (Accessed March 12, 2017). 